\title{
Blessed? A critical analysis of salvation in Denise Ackermann that portrays human flourishing as liberation, grace and the goodness of life
}

NGTT DEEL 55, NR 3 \& 4, 2014

Marais, $\mathrm{N}$

Stellenbosch University

\begin{abstract}
Happiness and human flourishing has increasingly become a theological research focus in a variety of theological disciplines, including systematic theology (cf Charry, 2012), practical theology (cf Long, 2012) and biblical theology (cf Strawn, 2012). In systematic theology the focus of such research often is often creation, salvation and eschatology. The doctrine of salvation has particularly interesting (including etymological) connections with the notions of well-being and health. This paper, which forms part of $\mathrm{PhD}$ research on human flourishing, proposes to do a critical analysis of renowned Circle theologian Denise Ackermann's understanding of salvation, since (1) feminist theology (and feminist theologians) has a particular concern for the 'flourishing of all', and (2) African theological voices on human flourishing should contribute to the emerging theological thinking on human flourishing. In this paper, it will be argued that salvation in Ackermann's thought is infused with the vision for 'abundant life for all', which culminates with the notion of 'blessing'.
\end{abstract}

\section{KEYWORDS}

Human flourishing, Feminist theology, Liberation theology, Practical theology, Salvation, Christian doctrine

\section{TREFWOORDE}

Menslike florering, Feministiese teologie, Bevrydingsteologie, Praktiese teologie, Verlossing, Christelike leer 


\section{CONTACT DETAILS}

Nadia Marais

Assistant to the lecturer, Faculty of Theology, Stellenbosch University

Privaatsak X1, Matieland, Suid-Afrika, 7602

nadiam@sun.ac.za

\section{NOTE}

Paper presented with the title "Blessed? A Critical Analysis of Salvation in Denise Ackermann" at the Circle of Concerned African Women Theologians' conference (of the SU and UWC Circle chapters) at Stellenbosch University (8 May 2014), with the theme "Gender and Human Flourishing". This article is part of doctoral research for a $\mathrm{PhD}$ in Systematic Theology at Stellenbosch University, with the title "Imagining Human Flourishing? A Critical Analysis of Contemporary Soteriological Discourses." 


\section{INTRODUCTION}

Denise Ackermann, Extraordinary Professor at Stellenbosch University, ${ }^{1}$ describes herself as 'a feminist theologian of praxis' (Ackermann, 2014:14). She has written extensively on feminist (liberation) theology, ${ }^{2}$ spirituality ${ }^{3}$ and the South African context, ${ }^{4}$ ranging from concerns with Apartheid ${ }^{5}$ and church ministry ${ }^{6}$ to reproductive rights ${ }^{7}$ and HIV/Aids. ${ }^{8}$ Her latest (and last) book reflects on these and other issues from the perspective of 'ordinary blessings' (cf Ackermann, 2014).

Theology is "concerned with human suffering and emancipation", writes Ackermann (1996:33), and should therefore promote the full humanity of all who suffer and who are oppressed, including women (1988:17; 1996:33). Feminist theologies are, in short, 'for life' (Ackermann, 1997). ${ }^{9}$ A 'feminist theology of praxis', moreover, is "critical, committed, constructive, collaborative and accountable reflection on the theories and praxis of struggle and hope for the mending of creation based on the stories and experiences of women/marginalized and oppressed people" (Ackermann, 1996:34). Therefore there are important connections and tensions between theology and context (Ackermann, 1996:35). For her, "[t]he need to continue wrestling with the economic, social, political and spiritual implications of an analysis concerned

1 Denise Ackermann is also affiliated with the University of the Western Cape, where she was Professor of Practical Theology until her retirement in 2000 (Pillay, Nadar \& Le Bruyns, 2009:6). In addition to this, she founded the Cape Town Chapter of the Circle of Concerned African Women Theologians (cf Pillay, Nadar \& Le Bruyns, 2009:6).

2 Cf "Feminist Liberation Theology" (Ackermann, 1988), "Defining our humanity" (Ackermann, 1992), and "Engaging Freedom" (Ackermann, 1996).

3 Cf "An Unfinished Quilt" (Ackermann, 1989), "A 'spirituality of risk' for Christian witness in South Africa" (Ackermann, 1994), and "Christian attitudes laid bare by two beatitudes" (Ackermann, 2008).

4 This threefold structure is also reflected in a festschrift that was recently dedicated to her, in which context (part 1), spirituality (part 2) and theology (part 3) partially structured the various dedications to her life and work (Cf Pillay, Nadar \& Le Bruyns, 2009).

5 Cf "A voice was heard in Ramah"' (Ackermann, 1998a), and "Becoming fully human" (Ackermann, 1998b).

6 Cf "Liberation and Practical Theology" (Ackermann, 1985) and "Differing Theories, Same Old Praxis" (Ackermann \& Armour, 1989);

7 "Reproductive rights and the politics of transition in South Africa" (Ackermann, 1995).

8 Cf Tamar's Cry (Ackermann, 2001).

9 Cf the doctoral dissertation by Ronell Bezuidenhout on the re-imagination of life in Denise Ackermann's work (2007). 
with the mending of creation remains central to the theological agenda", which, she argues, should include the incorporation of the legacies of Apartheid in theological reflections (1996:36).

Feminist theology (with its concern for resisting sexism and working toward the equality of all women), liberation theology (with its concern for socioeconomic-political justice and the struggle against societal exploitation of all forms (Ackermann, 1985:36)) and practical theology (with its concern for " $[t]$ he emancipatory nature of communicative actions" (1996:35)) are central tenets of Ackermann's theological agenda. There are particularly important links between feminist theology and practical theology ("in the sharing of certain methods and certain aims"), with liberation a key concept common to both feminist theology and practical theology (1985:38). Indeed, "[f]eminist liberation theology is in essence practical theology, that is it is committed to action and reflection in a reciprocal relationship" (Ackermann, 1985:24).

Ackermann prefers to speak of a feminist theology of praxis rather than a feminist practical theology ${ }^{10}$ because the former avoids the trap, she argues, of "reproducing traditional frameworks which essentially ask the same old questions" by merely recreating current male-dominated models of practical theology (1996:37-38). ${ }^{11}$ In other words, a feminist theology of praxis creates its own models and methods (Ackermann, 1996:38).

A feminist theology of praxis is concerned with salvation, in which justice - as 'right relation' - is taken seriously (Ackermann, 1992:15; Ackermann \& Armour, 1989:52). A feminist theology of praxis is concerned with redemptive acts of love

10 Although others describe her as a practical theologian (cf De Gruchy, 2007:33-34) and even Ackermann herself at times describe herself as a 'feminist practical theologian' (cf Ackermann, 1994:124).

11 In 1997, Denise Ackermann would describe feminist theologies' standing in relation to academic theology in South Africa as 'both, and neither' (1997:66). Primarily, she would argue that feminist theologies - including her feminist theology of praxis inhabit the spaces "on the periphery of theological discourses" (1997:67). This would entail both advantages and disadvantages (cf 1997:67). In addressing issues such as "the endemic nature of sexual violence against women and children" or "the widespread degradation of our environment" (which are two pressing issues for her), theologies from the margins are driven by "a profound longing for human wholeness" and "a better world" (1997:67). This would involve finding new images to describe Christian doctrines, such as theological anthropology (1988:19), because feminist theology of praxis is shaped by the interests of justice, liberation and well-being (Ackermann, 1996:38) or a "just, healing and liberating praxis" (1996:47). 
and liberation, which allow all human beings and the entire creation to flourish. A feminist liberation theology is key to understanding flourishing and salvation within Ackermann's thought, because her theological convictions underpin the variety of ways in which she views the formative, transformative and performative roles that Christian doctrine may play.

\section{FEMINIST LIBERATION THEOLOGY}

A feminist theology of praxis "seeks a political understanding of truth and theory and recognizes that the task of describing the relationship between God and humanity is intrinsically an historical and practical act", writes Ackermann (1996:42). This is so because feminist theology is, according to Ackermann (1985:33), rooted in two needs: (1) "the need for woman to reflect on human relationships and in particular on woman's relationship to God"; and (2) "the need to make theology, words of faith and church structures less one-sidedly male and more person-orientated" (1985:33). In short, feminist theology is born when a critical and systematic reflection on sexist oppression takes place 'in the light of faith' (1985:33).

Feminist theology, argues Ackermann (1985:30; 1988:16-17), looks to liberation as 'a key concept' because "[f]eminist theology arises from the historical reality of sexism in human society" (1985:33). Indeed, feminist theologies are, for Ackermann (1997:63), "critical theologies of liberation." Liberation, coupled with "a new vision for all of humanity" (Ackermann, 1988:17), has oriented theology toward praxis, and therefore the concern for liberation from (multi-dimensional) oppression (1988:17) shapes a feminist theology of praxis. However, not oppression but "the acceptance of the equal human worth of all in a just society" is feminist liberation theology's point of departure, argues Ackermann (1988:17). Feminist liberation theology "remains first and foremost a critical theology of liberation" (1988:17) which is particularly concerned with "the historical reality of sexism in human society" (1988:15). ${ }^{12}$

Yet, as Ackermann admits, "[t]here is ... no one feminist theology" $(1988: 15 ; 24)$ and even feminist theology itself "is not... without its own tensions" (1985:34). She

12 "I call myself a feminist theologian of praxis. I came to feminist theology through liberation theology. My early work was that of a feminist liberation theologian, because I was (and still am!) convinced that all theological theory is inextricably bound to Christian praxis. Feminist theological reflection meant exploring the legacy of patriarchal traditions and biased interpretations of scripture, and then trying to dismantle discriminating practices in the church. Its goal was to construct inclusive, affirming theories and practices for women - and for that matter for all who experience marginalisation and oppression" (Ackermann, 2009:270). 
herself distinguishes, for instance, between revolutionary and reformist feminist theologies (1988:16), or exclusive and inclusive models of feminist theology (1988:1617). The exclusive model of feminist theology "sees sexism as the key to all social oppression" while the inclusive model of feminist theology "views sexism together with racism, classism, etc. as one of the structures of oppression" (Ackermann, 1985:33; original italics; Ackermann, 1988:15). Particular points of tension between feminist theologians concern (1) experience (Ackermann, 1985:34-35), (2) the relevance of history and tradition (Ackermann, 1985:35), and (3) their visions for the future (Ackermann, 1985:35-36). Yet, even if it may not be possible to resolve all the tensions within feminist theology, a diversity of perspectives is regarded as a strength of feminist perspectives, in that they may be "mutually challenging and creative" (1985:36).

Denise Ackermann also explores the similarities and differences between feminist theology and liberation theology. An important similarity between feminist theology and liberation theology is that "theology is done by those who themselves belong to 'the exploited classes' and not on their behalf" (1985:37). An important difference between feminist theology and liberation theology is that " $t]$ he context of feminist theology is more universal than the class struggle of liberation theology ... [because] feminist theologians look at all structures, symbols and words which are discriminatory and oppressive" (1985:37).

In her description of the concerns of feminist theologies, Ackermann (1997:66) argues that feminist theologies are concerned with (1) "unmasking sexist practices in the church and in theology" and (2) exploring "hope, love and faith in the search for liberation and well-being." Yet feminist theology is also "undergirded by a holistic approach and the rejection of dualisms" (1994:127; footnote 3). Denise Ackermann employs images like mapping, remapping and exercises in theological cartography $(1996: 34 ; 43)$ to describe the tasks of a feminist theology of praxis. On her map of a feminist theology of praxis there are six clues or markers of importance: (1) critique and commitment; (2) constructive engagement and collaboration; (3) accountability; (4) struggle and hope; (5) the mending of creation; and (6) stories and experiences (1996:43-48). She admits that even her attempt at drawing a theological map or 'landscape of faith' may be incomplete or faulty, and that new maps may be needed. Indeed, "[t]heologians continue to be cartographers of changing contexts" (1996:49) and therefore "the need for revised maps for changing times will compel one to return to the drawing board again and again" (1996:49).

In short, Ackermann opts for 'the liberation perspective' which "manifests concern for the liberation of all people to become full participants in human society" because that she regards as "the most helpful perspective feminist theology can draw on" 
(1985:36). Therefore she would go so far as to argue that feminist theologies "have their genesis in liberation theologies, which in turn are part of the larger unfinished dimensions of theology" (1997:63). With such an understanding of "feminist liberation theology' in mind, the nature and function of Christian doctrine can be situated.

\section{NATURE AND FUNCTION OF CHRISTIAN DOCTRINE}

For Denise Ackermann, Christian theology is "the systematic reflection on and study of faith" (1985:30) - even more specifically, the task of theology is a systematic reconstruction of our religious symbols (1988:19). In her work she does not pay much attention to the nature and function of Christian doctrine as such, but in her systematic reflection on and study of faith three aspects of the nature and function of Christian theology emerge, which could arguably be indicative of Ackermann's thinking on the nature and function of Christian doctrine. ${ }^{13}$ Denise Ackermann's 'feminist theology of praxis' concerns the communicative, critical and experiential dimensions, which, in turn, play formative, transformative and performative roles in the shaping of Christian doctrine and Christian believers.

Firstly, a feminist theology of praxis is a practical theology, by which Ackermann (1996:35) means that it is "a theological operational communicative science

13 Ackermann's writing on feminist anthropology supports this argument: "The task of feminist liberation theology is to engage in a systematic reconstruction of our religious symbols which, in reflecting the relationship between humanity and God, are founded on a sexist bias. Such an exercise would require, among others, that we look at our God-language, Christology, redemption, our views on anthropology and on church and ministry" (1988:19). Moreover, she argues that a practical theology (such as her feminist theology of praxis) is necessarily inductive, which means that it "examines statements, symbols and acts that communicate Christian faith" leading to the formation of theological theories and the empirical verification or falsification of these theories (Ackermann, 1985:32) (which "does not necessarily or wholly exclude deductive methods" (Ackermann, 1985:37)). This does not mean that Ackermann has an interest in searching for an overarching system of thought - she prefers looking to "new ways of action which can bring about change" - but action and reflection belong together in her feminist theology of praxis (1985:37). Indeed, "[o]ur concern is with liberating praxis not with abstract universals" (1985:24). Moreover, the way in which a feminist theology of praxis should reflect on issues should be 'systematic' and 'documented', even if the verification of reflection is found in 'liberating praxis' (Ackermann, 1985:37). It is however clear not only that Ackermann values systematic reflection and reconstruction within a feminist theology of praxis, but also that this would involve Christian doctrine. Her discussion of a feminist theological anthropology is a clear example of this (cf Ackermann, 1988:19-24). 
in which reflection on the theory/praxis dialectic is central". ${ }^{14}$ This means that theology links knowledge with action and passion - and particularly involves the concern with suffering and oppression (Ackermann, 1996:33). Practical theology, writes Ackermann, "is the theological theory of Christian communicative actions" (1985:30) or "an operational science [which] contains both theory and praxis" (1985:31). The communicative plays a formative and performative role in shaping Christian doctrine and Christian believers. Indeed, Ackermann argues that theology "which is done in the service of believing, has a communicative dimension" (1985:30) and therefore opts for a theological point of departure in which "Christian communicative actions of faith" (1985:30) or "the communicative dimensions of Christian actions" (1985:40) are investigated. Theology, in this sense, is therefore not only formed but also 'performed': practiced, acted out, done in a variety of ways.

Secondly, a feminist theology of praxis involves reflection and critical engagement (Ackermann, 1985:30). Since practical theology has to do with "the complexity of the Christian communicative praxis" or "the communicative dimensions of faith" (1985:32), practical theology also implies systemic analysis (1996:37). A feminist theology of praxis should reflect critically on the communicative praxis particularly of oppressed groups (such as women), argues Ackermann (1996:38). Critical theological theories aim to articulate and account for conditions of oppression and suffering (1996:41). Yet critical reflection is also experimental, argues Ackermann (1985:37), in that it constantly raises "questions and tentative observations about a changing world" instead of providing final answers and conclusions.

For Ackermann, the critical task of a feminist theology of praxis has both an ethical dimension ("concerned with justice and equity within political, social, economic and religious structures and relationships") and a strategic dimension ("expressed in liberating praxis") (1996:41). These dimensions are inseparable in her thinking, as she explains in reference to her involvement in the South African anti-Apartheid activist group the Black Sash (1996:42; cf Klein, 2004:43-46; cf Ackermann, 1995:124; footnote 29) and the African theological society, the Circle for Concerned African Women Theologians (1996:42; cf Klein, 2004:50)). In short, “[a] feminist perspective assumes a critical stance" toward patterns of (especially sexist) oppression in human society (1985:33) and therefore plays both a performative and a transformative role in shaping Christian doctrine and Christian believers. Theological reflection

14 Interestingly, Ackermann (1985:30) notes that there are not one but two areas of debate in practical theology, namely (1) "the place of theology in practical theology" and (2) "the theory-praxis problem". She deals shortly with the former and extensively with the latter, and therefore this article will follow her in its focus on her description of 'the theory-praxis problem'. 
on and from Christian doctrine that engages in the task of critical engagement transforms but also performs the ethical and strategic dimensions of a Christian communicative praxis. A feminist theology of praxis is 'critical and committed' (Ackermann, 1996:43) in its "desire to engage with the multifaceted demands of emancipation and healing".

Thirdly, a feminist theology of praxis is experiential theology, orientated "towards particular issues which are rooted in experience" (Ackermann, 1996:37). The experience of oppressed people (including women) is a central category within a feminist theology of praxis (1996:48) - indeed, it begins "with systemic analyses that take the experiences of women and marginalized people into account" (1997:65). A feminist theology of praxis that roots itself in the contextual experiences of women is "compelled to grapple theologically with the effects that war, displacement, poverty, sexual violence, and the degradation of the environment have on the lives of women, children, and the poor" (1997:65). This, for Ackermann (1985:35), is women's contribution to "the unfinished dimension" and "open-ended journey" of theology - namely, experience. Experience plays both a formative and a transformative role in shaping Christian believers and Christian doctrine.

There are two divergent models of experiences that shape feminist theology, argues Ackermann (1985:34), namely (1) a feminist or liberation experience for women and (2) traditional experience for women. Ackermann hereby opposes experiences of freedom from sexist, male-centred cultures with experiences of rediscovering and revaluing that which sexist, male-centred cultures have rejected or denigrated (such as 'relational emotions') (1985:34). Yet the focus on experiences, as valid and important as it may be, also have dangers and limitations because "[o] ur personal experience is of necessity shaped by the reigning ideology of the society we live in" (1985:34).

Moreover, experiences are diverse, contradictory and contextual (1996:48) and therefore "not viewed as the sole arbiter of knowledge" (1996:48). Rather, "the diversity of women's experiences" has led to the formation of new and interesting theological perspectives. The point that the emphasis on the experiences of oppressed people wants to make is not that these experiences are monolithic or simple, but rather that "contextual issues are... profoundly theological" (1997:65) and therefore that experiences should play an important role in forming and transforming theological reflection. Indeed, a major strength of feminist theologies is its groundedness "in the concrete and material experiences of women and marginalized people", which enables feminist theologies to "move to theology and then back to praxis in the passionate longing for a better world" (Ackermann, 1997:67). 
Denise Ackermann's feminist theology of praxis is rooted in the communicative, critical and experiential. On the one hand, the communicative, critical and experiential forms and transforms Christian theology and Christian doctrine. On the other hand the communicative, critical and experiential nature and function of Christian theology and Christian doctrine forms and transforms people of faith. Yet Christian doctrine is also 'performed' in the many ways in which theology is practiced. Arguably then, the nature and function of Christian doctrine therefore culminates in the formative (communicative and experiential), transformative (experiential and critical) and performative (communicative and critical) roles that a feminist theology of praxis could play. The formative, transformative and performative roles at play in engaging with Christian doctrine give expression to a variety of methodological strategies in interpreting Christian doctrine.

\section{METHODOLOGICAL STRATEGIES IN INTERPRETING CHRISTIAN DOCTRINE}

A feminist theology of praxis engages Christian doctrine, argues Denise Ackermann (1997:65), primarily with regard to hermeneutics. She is of the opinion (1997:65) that " $t]$ he continuous questioning of Christian doctrines, the search for inclusive theological anthropologies, new understandings of the Trinity and Christology, have been a breath of fresh air in the hallowed halls of systematic theology." Ackermann moves from a 'hermeneutic of suspicion' (cf Ackermann \& Armour, 1989:53; cf Ackermann, 1992:17), to a "reading 'for life' hermeneutic"15 within a feminist theology of praxis, which has both its "moments of suspicion" and "moments of creative reconstruction" when reading the bible (1997:66).

It is with this 'for life' hermeneutic in mind that the collection of interrelated methodological strategies that Ackermann employs in interpreting Christian doctrine is examined. These can be loosely grouped into the categories of (1) theoria, (2) praxis and (3) poesis. ${ }^{16}$

15 Which she has also, elsewhere (1998a:80), called a 'hermeneutic of healing', by which she means that "all theological theories and all theological praxis must be measured by their ability to contribute to the healing of my country" (1998a:80).

16 She outlines these "basic ways of knowing, living, doing and being in the world" (according to classical philosophy) in her argument for the close relationship between praxis and theoria in Christian (feminist) theology (1996:41). In her description she includes a fourth mode, namely techné (which "referred to acts of application and doing") (1996:41), which this article does not regard as a methodological strategy in her work. The reason is twofold: (1) not only does she herself choose not to employ this strategy, but more importantly (2) she repeatedly argues for the deeply interrelated and 
Christian theology, firstly, has to do with the methodological strategy of theory - with "observing, interpreting and evaluating critically" (1996:41). Theory, like praxis, is an indispensable aspect of a practical theology (Ackermann, 1985:31). Denise Ackermann derives theological theory from "faith in the person of Jesus Christ and his tradition-history applied to the concrete contemporary situation of the church" (1985:31). As such, theories are directive, yet provisional (1985:31).

Christian theology, secondly, has to do with the methodological strategy of praxis with "the intentional practical engagement whereby people sought to do something for the common good" (1996:41). She adds that praxis "has become the technical term for the action/reflection mode of learning and teaching" (1996:41). Praxis, like theory, is an indispensable aspect of practical theology (Ackermann, 1985:31). Denise Ackermann describes praxis as "action concurrent with reflection or analysis, which should in turn lead to new questions, actions or reflections" (1985:31). Yet praxis is not synonomous with practice in Ackermann's thinking. Christian practices are both theological and normative, but for Ackermann the word praxis means something more - namely, "a practice that has been informed by theory, that has been reflected on" (Klein, 2004:45). Praxis, in short, is "faith in action" (Ackermann, 1985:32).

Much of Denise Ackermann's work is devoted to keeping theory and praxis together (cf 1996:41-43). Herein lies a key methodological insight into Ackermann's work - namely, that " $\mathrm{t}$ ] here is neither pure theory nor pure praxis... [ $t$ ]hey are neither totally separate nor totally identified" (1985:31). ${ }^{17}$ She argues (Klein, 2004:51) that

To stay in the realm of theory makes it much easier to avoid the reality of praxis. I cannot separate theory from praxis. For me, what I believe and what I do about what I believe, are inseparable. In my theology, what I believe and what I theorise about has to find feet in praxis ... Christ's ministry was no just sermons and teachings; it was a praxis of healing, a praxis of caring, a praxis of being with those who were marginalised, and

mutually shaping force of theory and praxis (cf Ackermann (1996:41), where she argues for "praxis as theory" and "theory as praxis"), so that a mere application of theory as in her description of techné - would be untrue to her theological methodology. Her protest against reason becoming technique instead of praxis is that theory thereby becomes divested of its substantive content, "including notions of justice, freedom, and human happiness" (Hewitt, 1995:9 in Ackermann, 1996:41).

17 Theory-praxis is an indispensable aspect of a practical theology, in Ackermann's work (1985:31) - yet Ackermann herself argues for three further aspects of a practical theological methodology, namely a future orientated, inductive and interdisciplinary approach (1985:31-32). 
ultimately a praxis of dying, because that was what was demanded of him. It was an iconoclastic praxis.

The relationship between theory and praxis that Ackermann envisions is 'a state of bipolar tension' (1985:31) in that "praxis can ... dictate theological reflection" (1985:32) and that theorising is also a practical activity (1996:41). It is a tension between 'what we believe' and 'what we do about what we believe' (Klein, 2004:45). Stated somewhat differently, it could be said that "[r]eflection on praxis shapes our theories that, in turn, translate into renewed praxis for healing" (1997:65) for "[o]ur theories have to stand the test of practice" (Klein, 2004:52).

Christian theology, thirdly, has to do with poesis - with "the creative imagination or the evoking of images which could be discovered aesthetically" (1996:41). Indeed, as Ackermann herself argues (1996:43), the required critical edge to the demands of emancipation and healing must be augmented by the allowance "for creativity, flexibility and attentiveness". Poesis, like theoria, is intricately linked to praxis (Ackermann, 1996:42), in that imagination and the ability to envisage a better world form part of the work of healing and reconstruction in our society (Ackermann, 1996:44).

In Ackermann's work, there are two modes of doing theology which exemplify this. The first theological mode in which she moves is that of telling stories in a variety of ways. "Our stories constitute our identity" in that we all have a 'narrative identity' (Ackermann, 1998b:24), and therefore "[t]elling stories breaks the silence which blankets the lives of women and other marginalized and oppressed people and is thus intrinsic to the healing of our diverse communities" (Ackermann, 1996:48). The theological mode of telling stories is vital to liberation and transformation, argues Ackermann (1996:48), because "they contain some of the very stuff that nurtures relationships and opens up possibilities for healing." ${ }^{18}$ Stories (1) claim identity, (2) names evil and (3) makes sense of seemingly nonsensical experiences (Ackermann, 2001:18-19). It is of particular importance to Ackermann that the life stories of those who have been oppressed are heard and reflected upon, because these stories hold the potential for transformation of both the oppressed and their oppressors

18 "We hear and speak different stories," which, upon hearing the stories of the other, "changes my story forever ... Telling our stories, hearing the stories of others, allows our stories to intersect. Sometimes they conflict, accuse and even diverge greatly; sometimes they attract, connect and confirm. As our stories touch one another, they change, and we too are changed" (Ackermann, 1998b:24). This is risky for those telling their stories, because it means acknowledging that "our views are only partial and that... our own identities are complex" (Ackermann, 1994:125). 
(1996:48). ${ }^{19}$ Indeed, "[i]t is only when hearing and telling stories begins as a process of openness, vulnerability and mutual engagement that alienations of class, race and gender can be challenged" (1996:48).

Yet hearing and telling stories are not enough, argues Ackermann (1996:48). There is a challenge that stories pose to their hearers that must be accepted - namely, "the challenge to act as agents for the mending of creation" (1996:48). Stories accentuate the capacity for and necessity of political and personal transformation (1996:48).

The second theological mode which exemplifies poesis in Ackermann's work is telling stories by way of theological letter writing. She explains how she came to "write letters to people who matter to me, about the themes that have been at the core of my search for healing and freedom" (2003:xii) in a book with the subtitle Letters from a Landscape of Faith (2003). For her, writing letters was "a vehicle to keep me from academic excesses", from the theological jargon of academic theology (2003:xii). This she would describe as a venture in doing theology simple and straightforward' (2003:xii; cf Smit, 2009). However, for her there would be an even

19 Elizabeth Tapia (2004:324) thinks that "[t]he themes and issues embedded in her stories are relevant today", but Christina Landman (2000:235-236) is highly critical of theological storytelling as practiced by Ackermann and other Circle theologians. Firstly, argues Landman (2000:235), a book like Claiming our Footprints (Ackermann et al, 2000) contains a variety of women's stories, but upon closer reflection these are the stories of women who are "mainly white and Christian, some of whom do not hold South African citizenship" and who do not, therefore, "represent South African women in general". Not only are stories like these therefore a misrepresentation of the realities of South African women, but they "[cause] pain to South African women rendered voiceless by other women" (2000:235). Secondly, for Landman (2000:235), this particular book "does not contribute to feminist theologies' body of knowledge, either locally or internationally", and thereby "raises the question of why the book was published." She regards this book as "light reading" and is of the opinion that "one finds more interesting stories better written in popular lifestyle magazines" (2000:236). Thirdly, Landman (2000:235-236) remains unconvinced that the private stories told by the contributors to this book is anything more than "the private stories of privileged women who are unable to integrate their stories into the bigger story of women in South Africa today" - in short, "the private remains private" and the stories therefore lack a broader public significance or performance. Stories that do not contribute to an analysis of society or that do not make substantial recommendations for the healing of those marginalised by society are too limited for where South African feminist theological discourses should have been by the time that this book was written (Landman, 2000:236). Yet stories may yet have a role to play in South Africa - as Landman (2000:236) admits, such stories are "a source of women's experience and an important beginning to the retrieval of women's voices in South Africa." 
more significant reason for this way of doing theology - namely, that she believes that the method chosen for communicating points to the kind of theology that she wants to practice (2003:xv). The art of letter writing follows a certain theological method, which "draws from experience that is submitted to critical scrutiny and tested within the social and political milieu in which it is shaped" (2003:xv). This entails narratives, or the telling of (personal) stories (2003:xvi; cf Loades, 2004:349). The art of theological letter writing is, moreover, autobiographical: "[G]iven the method I have just described, these letters have drawn me into writing about myself" (2003:xvi). This means that the personal and the public become interwoven, ${ }^{20}$ for together they tell the stories of a person's life (2003:xvi). John de Gruchy would call the art of writing letters to family and friends a 'genre' in doing theology (De Gruchy, 2009:175). He writes that the advantages to doing theology in this way includes not overwhelming readers with footnotes, in that - in letters - "you have to say what you mean up front" (De Gruchy, 2009:175). "You must speak from your own experience and perspective" and yet, "[a]t the same time ... explore issues in some depth if it is to be theological at all” (De Gruchy, 2009:175). ${ }^{21}$

20 John de Gruchy (2007:33-35), Selina Palm (2012:367-368), Flora Keshgegian (2004:87) and Ann Loades suggest that Ackermann's theology can be described as 'public theology' - by which De Gruchy (2007:35) means that Ackermann functions "on the boundaries between the academy, the church, and secular/political society"; and Palm (2012:368) means "Ackermann's distinctly uncompromising passion for the tough questions of life"; and Keshgegian (2004:87) and Loades (2004:349) means that it becomes clear in Ackermann's writing that faith cannot merely be a private matter. Spirituality is an important aspect of such an understanding of Ackermann's practical, public theology. Indeed, for De Gruchy it is Ackermann's spirituality that "shapes her public theology most profoundly" (2007:35).

21 Flora Keshgegian (2004:87) remarks that " $\mathrm{t}]$ he epistolary form is a bold move for a theological text" in the sense that although "more and more theologians and scholars have been writing memoirs, few have ventured into inscribing their thoughts in the form of letters." Elizabeth Tapia (2004:324) appreciates Ackermann's many references and notes within her letters, but mentions two challenges to her 'extended letters': (1) "she does not deal much with critical analysis of power and dominance"; and (2) her letters lack more references to "works of black African theologians" which "would have added the richness". Yet for Keshgegian (2004:88) Ackermann's theological work has been critical - "not only of the racial politics of whites and Afrikaners, but also of the gender bias and patriarchal oppressiveness of much Christian theology." She (2004:87 is of the opinion that Ackermann makes good use of the theological genre of letter writing by writing "in an engaging and accessible style, ably weaving theory with reflection, autobiographical detail with historical and political analysis.” 
Denise Ackermann arguably employs the interrelated methodological strategies of theoria, praxis and poesis in her 'for life' hermeneutic in interpreting Christian theology and Christian doctrine. Christian doctrine, which has to do with the communicative, critical, and experiential aspects of Christian theology, forms, transforms and performs Ackermann's understanding of salvation as freedom and grace.

\section{SALVATION AS FREEDOM AND GRACE}

Denise Ackermann is highly critical of "a personal and otherworldly salvation" because it may exclude "meaningful change and the risk of transformation" (Ackermann \& Armour, 1989:55). Rather, salvation has to do with both freedom and grace, because "a feminist liberatory approach seeks that which is freeing and whole-making for both women and men" (1992:14).

Salvation is performed in freedom, which transforms - or frees - human beings and human society. "[L]iberation," writes Denise Ackermann (1985:36), "is a core concept at the very heart of the Christian gospel... the gospel offers liberation from sin and guilt - a vision of what it means to be a liberated sinner." Salvation in Ackermann's work has a clear concern with liberation and freedom. However, salvation concerns more than just the freedom from sin and guilt. The liberating power of the Christian faith also has to do with the socio-cultural and political, with the abolishment of injustice and the building of a new society (1985:36) - in short, with transformation. ${ }^{22}$ Salvation is performed in 'doing theology', such as working against slavery and racial oppression.

Salvation, for Ackermann, also has to do with transformation, which she describes as "a passion for change" (1996:45). Transformation has to do with both hope and struggle, with both eschatology and history (1996:46). However, salvation in Ackermann's thinking mainly has to do with freedom, and therefore with vulnerability (1996:45): "Any person who invests her or himself in the freedom of the other as an end in itself, embraces vulnerability, a beautiful yet painful concept and one which causes many feminists and oppressed people to recoil." It is in vulnerability that both hope and struggle can be embraced; or, stated somewhat differently, "there is no change without vulnerability and risk" (1996:45).

22 This is exemplified in, for instance, Ackermann's advocacy for a 'transformative' understanding of theological anthropology; a model which is "directed at the attainment of full personhood for both men and women, whilst realising the simultaneous need for societal change" (1988:22-23). 
As important as human beings are to Ackermann, transformation also involves the ecology, in what she calls the mending of creation ${ }^{23}$ (1996:45). The mending of creation involves transformation by love, in which good relations among human and non-human beings are fostered, and which "speaks of justice, love, freedom, equality and the flourishing of righteousness" (1996:47). Mostly, though, "the mending of creation rests on transforming our relationships with ourselves, with one another, with God and with our environment through actions for justice and freedom" (1996:47). Salvation then, firstly, has to do with performing and transforming freedom.

However, salvation in Ackermann's thought also - secondly - has to do with (both ordinary and extraordinary) grace (2014:36): 'ordinary', because grace is often found "in the order of things", as "a commonplace reality, flooding the world, there for all, from the beginning of time" (2014:36-37); and 'extraordinary', because grace "cannot be earned", "is unmerited and utterly abundant" and "permeates the world" (2014:37). Salvation is a story of (unending) grace (2014:36), of "[o]ur story with God" (2014:36), with being made "from and for God" and one another (2014:37). Grace is both a gift and a revelation of who we are (2014:38). God's grace "is unfathomable and unmerited" (2014:39), "is for all creation" (2014:40), "pursues us" (2014:40), "is free, extravagant and transforming" (2014:41), and "enables us to respond to God in Christ" (2014:41). Grace has to do with being in relationship with God - a relationship of 'healing love' - wherein human beings are imbued with "the sense of being held and cared for" (2014:41). In Ackermann's thought, grace is practical, in that it 'performs' salvation: "Grace sanctions the forgiveness of sins, restores relationship, and enables love and hope" (2014:41). Grace is performed in its sheer givenness to us by God, but God also transforms human beings and the entire creation. Yet grace, like freedom, has to do with the inner logic of God's love, in that "grace declares God's love - and God can be no other than loving" (2014:44). Grace, for Ackermann (2014:37), has to do with blessing, because blessing means

23 Ackermann argues specifically for the use of 'mending' instead of 'healing' (although there are instances where healing and 'a healed world' are a part of her vocabulary to describe salvation as transformation), because she regards 'mending' as "a more encompassing and less psychologically oriented term" (1996:33; footnote 6). She understands 'mending' not as patching or fixing, but as "making whole again" (1996:33; footnote 6). 'Healing' and 'wholeness' are important companions in her work (cf 1994:125-126), in that both "[t] he work for healing and the search for wholeness begins with the search of justice" (1994:126). This is risky, because there are no guarantees of 'being healed' or of 'achieving the goal of wholeness'. Therefore the task of "seeking healing and wholeness in our society requires a communal vision based on a profound desire for justice and a commitment to stand in the truth" (1994:126). 
acknowledging "the working of God's grace in our lives." Salvation then, secondly, has to do with performing and transforming grace.

Salvation is God's purpose for humankind, argues Ackermann (2009:171); and salvation - as freedom and grace - is deeply concerned with "the blessing of being in sustained and loving relationship with the Ground of all Being" and "a world in which God will be at home in us" (2009:173). Freedom and grace are therefore also plays a formative role in shaping the identities of believers and faith communities. Salvation, as the formation, transformation and performance of freedom and grace, is a redemptive and loving blessing. For if God is a God "who pours out Godself to us" because "[t]otal self-giving is the very nature of our God" (2009:166), then salvation points to the blessings of being loved and being made to love. The intricate connections between salvation, love and blessing in Denise Ackermann's thought and work comes to expression in her understanding of the flourishing of human beings and the whole of creation.

\section{BLESSED HUMAN BEINGS?}

Forming, transforming, and performing freedom and grace culminate in the vision of the flourishing of all human beings and the entire creation. Denise Ackermann repeatedly employs the term 'flourishing' in relation to well-being and salvation in her work, but does not provide a clear definition of the term in any of her books or articles. Ackermann does, however, employ 'flourishing' in close proximity to such terms as 'wholeness', 'healing,' 'well-being,' 'blessing, 'fulfilment', 'liberation, 'justice' and 'love. ${ }^{24}$ Flourishing is also clearly opposite to 'subordination', 'discrimination' and 'oppression' (Ackermann, 1992:18) - indeed, "[t]o liberate people to live a life of dignity that affirms their worth is very difficult in situations of oppression, discrimination and poverty" (Klein, 2004:41). She has a particular concern for the well-being of all, which "can be discerned through feminist analysis" and which "is grounded in our relationship with God, with one another and with creation" (1996:45).

In Ackermann's thought, the relational aspect of flourishing is of great importance. "[R] elationship," writes Ackermann (1998b:17), "is central to our being and to our well-being." It is, however, difficult to define. What it is not, argues Ackermann (1998b:17-18), is alienating, apathetic, isolating, separating or oppressive. Rather,

24 Ackermann does not, however, have much affinity for 'happiness' in her work - for instance, in one of the few instances where she references happiness directly she does so only within the context of an argument on progress which is measured in expanding capital growth (cf 1997:64). 
right, loving and just relationships are mutual - "concerned with the feelings, needs and interests of each other (sic)" - and reciprocal - "created out of mutual interdependence" (1998b:18). "My humanity is found, shaped and nurtured in and through the humanity of others," argues Ackermann (1998b:18), and therefore "there is no growth, happiness or fulfilment for me apart from other human beings." For her, humanity is precious (Ackermann, 1989:75). Moreover, since God's (covenant) relationship with us is characterised as being loving and just - involving 'unconditional love, 'ongoing presence,' 'justice,' 'peace' and 'wholeness' - we too are called to practice loving and just relationships (Ackermann, 1998b:21).

For Ackermann, relationship and the practices are inseparable, in that "[f]aithful Christian practice can only be ethical, effective and relevant if it takes seriously the challenge of relationship in difference and otherness" (1998b:22). Relationship is not "an abstract theological truth" but is practiced "with our entire being - our bodies, our emotions and our minds - in what we see, hear, say and do" (1998b:23). In short, being fully human means living in relationship (Ackermann, 1998b:20) because it means acknowledging that "I am not complete unto myself" (1998b:23), that "there is no full humanity without the other" (Ackermann, 1998b:25; original italics). Full humanity, or 'authentic existence', "is living as a fully human part of a whole in mutual relationship, participating not possessing, needing one another, knowing that we belong to one another" (Ackermann, 1998b:22). This means grappling with "the challenges, implications, and surprises of seeking to be in relationship with each other in all our difference and otherness, in the fullness of our humanity" (1998b:27).

Relationality is the expression of love for self and neighbour in that "[a]ctive loving of self and neighbour" is "the praxis of right relationship" (1992:20). There is an intricate bond between relationality and love within Ackermann's work, which is embedded in a feminist theological anthropology that values a praxis based on love and justice (1992:20-21). Relationality, however, is the opposite of 'alienation' (1992:21), 'spiritual deprivation' (1992:21), 'apathy' (1992:21), 'sexism' (1992:21), 'racism' (1992:22), and 'classism' (1992:22), 'ageism' (1992:22). Relationality is both a need and a priority (1992:22), which links us to our 'created nature' (1992:22) and "finds its source in our understanding of the God as God in relation" (1992:22; original italics). The key for understanding this God-in-relation is Jesus, 'the man on the borrowed donkey', who is the model and the guide into a transformative anthropology (1992:23). Relationality is the basis for a transformative anthropology, in which the full humanity of all (including women) are affirmed (1992:23). Finally, the vision of the flourishing of all human beings is undergirded by such 
a transformative anthropology, which is "concerned with our relationships with ourselves, with one another, with God and with our environment" (1992:23).

Denise Ackermann's notions of blessing and flourishing are also particularly closely connected. ${ }^{25}$ For her, 'abundant life' points to "a new intensity of living", of being "fully alive" (2014:27). 'Abundant life' is all that is "fulsome, affirming, redolent with promise" and is encapsulated in three words: compassion, love and hope (2014:28). 'Blessing', then, articulates what she understands as being 'fully alive' (2014:27) - in her words, "[e]xploring blessing is in essence finding out what it means to be a fully free human being" (2014:26). She explains her understanding of what 'blessing' is (and is not) as follows (2014:26-27):

Feeling blessed is not an uninterrupted good feeling. It is not financial security, nor physical well-being. It is not lasting pleasure, nor happiness, nor an unendingly cheerful mood. Being blessed is not some abstract faith concept of spiritual well-being. Being blessed does not mean that life becomes an easy ride. A sense of blessedness is challenged by the exigencies of life... [Moreover, b] eing blessed is not an abstract theological concept. It is a practice, a way of living, not an esoteric truth. There is nothing majestic or mysterious about being 'blessed'. It is about living in a way that makes the promise of abundant life possible, even in daunting circumstances. Being blessed is expressed practically in prosaic matters such as affirming another with a loving word, feeding the hungry, giving water to the thirsty, welcoming the stranger and caring for those in need.

Yet Ackermann's understanding of blessing is inseparable from what she describes as her 'longing for the man on the borrowed donkey'26 (2014:26). Theology has to

25 She writes about the complexities surrounding her choice of 'blessing' as follows (2014:26): "Being 'blessed' has an overtly pious ring. As I wrote the blessings that follow in this book, I struggled to find similar words that sounded less 'religious', words like 'happy', 'privileged,' 'favoured', and so on. But in the end I decided that 'blessing' actually says it all even if it needs 'decoding'".

26 Ackermann's reference to Jesus of Nazareth as 'the man on the borrowed donkey' is pivotal to her feminist theology of praxis (and her relationship with Jesus, she would add) (2014:23). She writes that "[i]t is an expression that has a touch of the comical, and that is laced with paradox and incongruity when it is used for the central figure of my faith" (2014:23). Perhaps even more telling is her explanation of how she came to this particular phrase (2014:23): "I remember that morning all too vividly. Sitting at the very end of the nave near the high altar of Canterbury Cathedral, I watched the bishops of the Anglican Communion enter and take their seats under the soaring, ribbed Gothic ceiling of that historic building. Clothed in robes of brocade, silk and 
do with 'living fully', which entails the acceptance of the ambiguity of life and living (Ackermann, 2000b:172). Yet it is the spirituality born in the alchemy of risk, struggle and hope that would sustain us through life, "in good and bad times" (2000b:171). Spirituality - that which touches upon "the deepest parts of our being where our feelings, thoughts, beliefs and praxis reach out in faith for the wholeness imaged in us by God in Jesus Christ" and which "enables us to truly love God, ourselves and one another" (1994:125) - expresses this longing in her work. Spirituality "is a journey of self-discovery and God-discovery - of knowing yourself and knowing God" (2009:276) which has, at its core, to do with how Ackermann understands blessing. For her, blessing means (1) holding onto Jesus' promise of abundant life and (2) hearing and obeying Jesus' commands (2014:26-27). She clearly makes the point that blessing, for her, is no mere superficial or fleeting thought or emotion, but a deeply existential and spiritual struggle. In the struggle to live with love and the courage to hope, we learn about blessing (2014:27) - moreover, it is Jesus that gives and is able to give 'abundant life, ${ }^{27}$ by offering human beings the triad of compassion, love and hope (2014:28).

Compassion, the first element within Ackermann's triad of abundant life, is a 'gut reaction', which entails "to suffer with someone" or "to enter into a person's situation and become involved in that person's suffering" (2014:28). Compassion is more than theory - 'thinking' or 'saying' - argues Ackermann (2014:28): "[c]ompassion is practical", and therefore moves us to 'alleviate suffering', 'oppose injustice, and to be concerned for "the dignity and worth of all people without exception." Compassion has to do with a practical expression of love (2014:28-29).

Love, the second element within Ackermann's triad of abundant life, is inseparable from compassion (2014:29). Yet love does not come from human beings in themselves, who love because God first loved them. For Ackermann (2014:29), "[t] he foundation of love is God's love freely given" which "awakens our ability to love

even gold lame, embroidered with indigenous themes, mitres on heads, among them a handful of women, they entered the cathedral with measured tread. I found myself straining forward as the doors closed slowly behind the Archbishop of Canterbury. What was I hoping to see? Then I realised and was surprised by the image that popped into my head. I was looking for 'the man on the borrowed donkey'! Where, amidst all this pomp, was Jesus whom I had come to know and love and who had changed my life?"

27 Even more - for feminist theologies, Jesus is the model of 'full humanity' (1992:17), which "includes women, men, and children, infected and affected" and "[strives] to uphold the integrity of life, value the dignity of the (sic) human beings including those who are on the margins or who are excluded" (Björk, 2006:317). 
in return." Love means to be 'affirmed', 'desired' and 'accepted'. Love is more than affections or intimacy or the erotic - "[l]ove (like hope) is a practice or a way of life, often fraught with difficulties, sacrifice, frustrations" (2014:29). Love is both an obligation (of "living as a moral person") and a gift from God, for Ackermann (2014:30): it is "for the flourishing of creation." ${ }^{28}$ Ackermann consequently argues that love ought to be understood in relational terms (2014:30):

Love is about how I relate to God, others, myself and to the world in which I live. Love is to risk trust and commitment. Love means creating space for another in which she can flourish, while at the same time she does this for me. This is love that is mutual - my desire for the well-being of the other is related to his desire for my well-being. Her fulfilment is my fulfilment.

In short, "[t]o love is to be in relationship" (Ackermann, 1998b:20). Not only are human beings made to love and to be loved, however, but "[l] ove is our only salvation" (Ackermann, 2014:31). Love saves human beings from meaninglessness and "gives meaning to God's entire creation (Ackermann, 2014:31). Love gives content to Ackermann's understanding of salvation, but also calls upon human beings to hope.

Hope, the third element within Ackermann's triad of abundant life, means "never to surrender our power to imagine a better world, that present unjust arrangements are provisional and precarious and do not require acceptance" (2014:32) ${ }^{29}$ It does not mean "hoping for the end times when all will be made new" or "a false sense of fulfilment that believes that all is well" (2014:32). For Ackermann, hope "is not optimism" (2014:33), "is not vested in some future victory" (2014:34), "is to be lived" (2014:34), "is risky" (2014:34), "recognises the tragic in our history" (2014:35), "is learning to wait" (2014:35), and "is nurtured by prayer and community" (2014:36). Hope is 'a passion for the possible' because "God is the ground of our hope" (2014:36).

28 Although, interestingly, Ackermann also includes the notion of 'self-love' when she writes on love in other contexts. She argues, in an article on the beatitudes (2009:165), that "we must love ourselves as we are ... to love ourselves is to rest in God in whom alone is our hope." In an earlier article, on a feminist theological anthropology, she writes that relationality involves "the affirmation of self which enables us to love our neighbour as ourself" (1992:22). The acceptance of God's love comes to expression in self-love" (1992:22).

29 "To hope is to refuse to accept despair or defeat. It is our response to the dilemma of being both oppressors and oppressed. Hope is resistance. It actively avoids the void of hopelessness by wrestling with all that seeks to deprive us of hope and disempower us. It risks daily engagement in liberating praxis. It risks ambiguity, uncertainty and darkness" (Ackermann, 1994:126). 
Compassion, love and hope - the triad which describes the abundant life that Jesus gives to human beings - stand at the heart of Ackermann's understanding of 'blessing. It is therefore understandable that Ackermann would be highly critical of the belief that "the more helpless we are the stronger and greater that makes God" because this thinking causes us to "rob ourselves of our own capabilities and responsibilities" in waiting for God to act (1988:27). Feminist theology challenges such an understanding of God and human beings. The vision of the flourishing of human beings has to do with love - more specifically, with flourishing in vulnerability and powerlessness (1988:27). Liberation and flourishing are closely linked in Ackermann's understanding of salvation, in that "the gospel of love, justice and peace means to become involved in liberating praxis" (1988:27). This involves the elimination of discrimination of any kind, in order to afford dignity and justice to all created beings (1988:28). In short, God's love for each and every human being challenges us to exercise a 'world-transforming praxis', which works for justice and human dignity for all (1988:27).

For Ackermann, this is precisely what the beatitudes of Matthew 5:1-11 and Luke 6:20-26 embody. Her interest in the beatitudes stems from a concern for the ethical values within South African society (2009:158). She is particularly concerned with "the rampant materialism and acquisitiveness" and the "[u]nbridled violent criminality" that permeates South African society (2009:158-159). ${ }^{30}$ Not only are the beatitudes 'precise' and 'comprehensive', but they "contain a complete précis of Jesus' teaching" (2014:42) and "set out ethical norms, standards, and injunctions by which Christians are called to live" (2009:157). Here too Ackermann is concerned with "the practical application of what we believe to be right in our daily acts, in our relationships, and in our worship" - in short, with our 'ethical praxis' (2009:159). Indeed, the beatitudes "have stood as a moral beacon for all times" in that they are "the embodiment of Christ's teachings" (2014:42). She believes that the beatitudes "are intended to guide us on how to live freely and fully" (2014:43). Therefore she attempts "to describe different experiences of blessing" in her own set of 'ordinary blessings', in a book entitled Surprised by the man on the borrowed donkey (2014).

Flourishing, then, is 'abundant life': living 'fully' and 'freely', in relationship with God and others, with compassion, love and hope. Salvation, as freedom and grace, forms, transforms and performs the blessing of living fully and freely in human beings and human society. Indeed, "that which affirms the full humanity of all as

30 Elsewhere she emphasises violence in the South African society of 1994: "In South Africa at present, every aspect of our lives is lived out within the context of violence ... Violence in South Africa is endemic and normal" (Ackermann, 1994:123-124). 
created in the image of God" is considered 'redemptive', by Ackermann \& Armour (1989:54). Denise Ackermann's understanding of the flourishing of human beings and creation wants to balance "the concerns of liberation theologies for a healed world" (1997:64) with the advancement of the common good (1996:45). Her vision of the flourishing of (1) women and marginalised people and (2) the environment are expressions of her "passionate longing for a better world" (1997:67). Ultimately, her vision for the flourishing of human beings and the entire creation has to do with the vision of 'abundant life' and the powers of compassion, love and hope. Flourishing, however, also involves praxis: the practices of imagining a better world, storytelling and practical-ethical living - in short, with freedom and grace. To flourish is to be blessed and to be a blessing unto (human or nonhuman) others.

\section{CONCLUSION}

For Denise Ackermann, "feminist theology is a work of love" which entails "living towards freedom and refusing to settle for anything less (2009:272). Apart from being a feminist theologian of praxis (by her own admission) Ackermann also describes herself as 'a ragbag theologian' (wherein the ragbag is used as a metaphor for how she does theology) (cf Pillay, Nadar \& Le Bruyns, 2009). Calling herself a 'ragbag theologian' has been her way of "describing a love affair with theology" (Ackermann, 2009:272) - even more, the "never-ending, totally absorbing love affair" (Ackermann, 2009:281). Denise Ackermann ends her theological work - this 'love affair' - with a telling reflection on blessing. She argues that theology has to do with blessing because it has to do with the transformative power of salvation. Living fully and freely means embracing the vision of 'abundant life', which is the blessing of loving and being loved. Blessing is more than being fortunate or happy, however (Ackermann, 2014:43), for it

includes a sense of being privileged with divine favour, of being holy, hallowed. It means experiencing gratitude at receiving unmerited grace. It is about a sense of well-being because the goodness of life is affirmed and upheld against the odds. It asserts certainty at God's presence, mercy and care. God wants to bless us. All that is required from us is to do our best to love God and one another. Then we will be blessed for God's love can do no other. 


\section{BIBLIOGRAPHY}

Ackermann, DM 1985. "Liberation and Practical Theology. A feminist perspective on ministry." Journal of Theology for Southern Africa, 52:30-41.

Ackermann, DM 1988. "Feminist Liberation Theology. A Contextual Option." Journal of Theology for Southern Africa, 62:14-28.

Ackermann, DM 1989. “An Unfinished Quilt. A Woman's Credo.” Journal of Theology for Southern Africa, 66:74-78.

Ackermann, DM and Armour, M 1989. "Differing Theories, Same Old Praxis. Some Feminist Thoughts on Right Wing Religion." Journal of Theology for Southern Africa, 69:53-59.

Ackermann, DM 1992. "Defining our humanity: thoughts on a feminist anthropology." Journal of Theology for South Africa, 79:13-23.

Ackermann, DM 1994. 'A 'spirituality of risk' for Christian witness in South Africa." International Review of Mission, 83(no 328):123-128.

Ackermann, DM 1995. "Reproductive rights and the politics of transition in South Africa." Journal of Feminist Studies in Religion, 11(2):117-127.

Ackermann, D. M. 1996. "Engaging Freedom: A Contextual Feminist Theology of Praxis." Journal of Theology for South Africa, 94:32-49.

Ackermann, D. M. 1997. "Forward from the margins. Feminist theologies for life." Journal of Theology for South Africa, 99:63-67.

Ackermann, DM 1998a. “'A voice was heard in Ramah': a feminist theology of praxis for healing in South Africa." In Ackermann, DM and Bons-Storm, R (eds) Liberating Faith Practices. Feminist Practical Theologies in Context. pp 75102.

Ackermann, DM 1998b. "Becoming fully human: An ethic of relationship in difference and otherness." Journal of Theology for South Africa, 102:13-27.

Ackermann, DM 2000a. "Claiming our footprints - introductory reflections." In Ackermann, D. M., Getman, E., Kotzé, H. and Tobler, J. (eds) Claiming our footprints. South African women reflect on context, identity and spirituality. Ecumenical Foundation of Southern Africa (EFSA) Institute for Theological and Interdisciplinary Research. pp 5-14. 
Ackermann, DM 2000b. "A letter to my Granddaughters on matters of the heart." In Ackermann, DM, Getman, E, Kotzé, $\mathrm{H}$ and Tobler, J (eds), Claiming our footprints. South African women reflect on context, identity and spirituality. Ecumenical Foundation of Southern Africa (EFSA) Institute for Theological and Interdisciplinary Research. pp 161-175.

Ackermann, DM, Getman, E, Kotzé, H and Tobler, J (eds) 2000. Claiming our footprints. South African women reflect on context, identity and spirituality. Ecumenical Foundation of Southern Africa (EFSA) Institute for Theological and Interdisciplinary Research.

Ackermann, DM 2001. Tamar's cry: re-reading an ancient text in the midst of an HIV/Aids pandemic. Ecumenical Foundation of Southern Africa (EFSA) Institute for Theological and Interdisciplinary Research.

Ackermann, DM 2003. After the Locusts. Letters from a Landscape of Faith. Grand Rapids, Michigan: William B. Eerdmans Publishing Company.

Ackermann, DM 2008. "Christian ideals laid bare by two beatitudes." In Rowland Jones, S (ed.). Faith in Action. Njongonkulu Ndungane: Archbishop for the church and the world. Wellington: Lux Verbi. pp 157-176.

Ackermann, DM 2009. “'Found Wanting and Left Untried?' - Confessions of a Ragbag Theologian." In Pillay, M, Nadar, S and Le Bruyns, C (eds), Ragbag Theologies. Essays in honour of Denise M Ackermann, a feminist theologian of praxis. Stellenbosch: SUN Press. pp 267-282.

Ackermann, DM 2014. Surprised by the man on the borrowed donkey: ordinary blessings. Unpublished manuscript.

Bezuidenhout, R 2007. "Re-imagining life: A reflection on "public theology" in the work of Linell Cady, Denise Ackermann, and Etienne de Villliers". D Phil dissertation, Department of Biblical and Religion Studies, Nelson Mandela Metropolitan University.

Björk, S 2006. “The Unveiling of the Patriarchal Church: African Women Theologians in Search of Ecclesiological Transformation in the Struggle against HIV and Aids." Swedish Missiological Themes, 94(3):305-322.

Charry, ET 2012. "The Necessity of Divine Happiness: A Response from Systematic Theology." In Strawn, B. A. (ed.) The Bible and the Pursuit of Happiness. What the Old and New Testaments Teach Us about the Good Life. New York: Oxford University Press. pp 229-248. 
De Gruchy, JW 2007. "Public Theology as Christian Witness: Exploring the Genre." International Journal for Public Theology, 1:26-41.

De Gruchy, JW 2009. "On Locusts and Wild Honey - Letter Writing as Doing Theology." In Pillay, M., Nadar, S. and Le Bruyns, C. (eds), Ragbag Theologies. Essays in honour of Denise M. Ackermann, a feminist theologian of praxis. Stellenbosch: SUN Press. pp 175-181.

Hewitt, MA 1995. Critical Theory of Religion: A Feminist Analysis. Minneapolis, Minnesota: Fortress Press.

Keshgegian, FA 2004. Book review of Ragbag Theologies: Essays in Honour of Denise M. Ackermann, a Feminist Theologian of Praxis by Pillay, M, Nadar, S and Le Bruyns, C (eds), Reviewed in Theology Today, 61(1):87-88.

Klein, B 2004. "On becoming and being a woman theologian in South Africa: in conversation with Denise Ackermann." Journal of Theology for Southern Africa 118:40-52.

Landman, C 2000. Book review of Claiming our footprints. South African women reflect on context, identity and spirituality by Ackermann, DM, Getman, E, Kotzé, H and Tobler, J (eds), Reviewed in Religion and Theology, 7(2):230-237.

Loades, A 2004. Book review of After the Locusts: Letters from a Landscape of Faith by Ackermann, DM, Reviewed in The Expository Times, 115(10):349.

Long, TG 2012. "A Constructed Happiness: A Response from Practical Theology." Strawn, BA (ed.), The Bible and the Pursuit of Happiness. What the Old and New Testaments Teach Us about the Good Life. New York: Oxford University Press. pp 249-262.

Palm, S 2012. Book review of Ragbag Theologies: Essays in Honour of Denise M. Ackermann, a Feminist Theologian of Praxis by Pillay, M, Nadar, S and Le Bruyns, C (eds), Reviewed in the International Journal of Public Theology, 6:367-368.

Pillay, M, Nadar, S and Le Bruyns, C (eds) 2009. Ragbag Theologies. Essays in honour of Denise M. Ackermann, a feminist theologian of praxis. Stellenbosch: SUN Press. 
Smit, DJ 2009. "Simple and Straightforward? - On Doing Theology." In Pillay, M, Nadar, S and Le Bruyns, C (eds) Ragbag Theologies. Essays in honour of Denise M. Ackermann, a feminist theologian of praxis. Stellenbosch: SUN Press. pp 157-174.

Strawn, BA (ed.) 2012. The Bible and the Pursuit of Happiness. What the Old and New Testaments Teach Us about the Good Life. New York: Oxford University Press.

Tapia, ES 2004. Book review of After the Locusts: Letters from a Landscape of Faith by Ackermann, DM, Reviewed in the International Journal for Public Theology, 8:324, 2003. 
